\title{
Effects of direct exposure to lead on some haematological parameters among battery repair workers in Mosul
}

\author{
Faris Y. Bashir* , Ali M. Al-Ameen**
}

Department of Pathology, Collage of Medicine, University of Mosul*, Ibn Sina Teaching Hospital, Lab., Mosul**.

(Ann. Coll. Med. Mosul 2008; 34(1): 58-63).

Received: 31 ${ }^{\text {st }}$ Dec 2007; Accepted: 23 ${ }^{\text {rd }}$ Apr 2008.

\section{ABSTRACT:}

Objectives: Determination of the degree of lead exposure and to study the possible effects of lead on different haematological parameters.

Methods: A haematological study of thirty battery repair workers and thirty-four blood donors (as a control) in the period of 2 months (January - February 1998). All the workers and the donors were subjected to a clinical and laboratory evaluation. The laboratory tests included complete blood picture, blood lead level determination and iron status study.

Results: Analysis of lead in the blood showed that the mean blood lead level (BLL) of these workers was significantly higher than that of the control $(P<0.001)$. 20\% of the battery repairers had symptoms, while $16.7 \%$ of them had normochromic normocytic anaemia and $23.3 \%$ had reticulocytosis. Iron status was normal in all of the repairers but it was found that transferrin saturation of the repairers with BLL of more than $70 \mu \mathrm{g} / \mathrm{dl}$ RBC was significantly higher $(P<0.05)$ than those repairers with BLL of or less than $70 \mu \mathrm{g} / \mathrm{dl}$ RBC.

Conclusion: Battery repairing is an important new source of lead exposure in our community and periodic medical supervision is required as well as improvement of their working conditions.

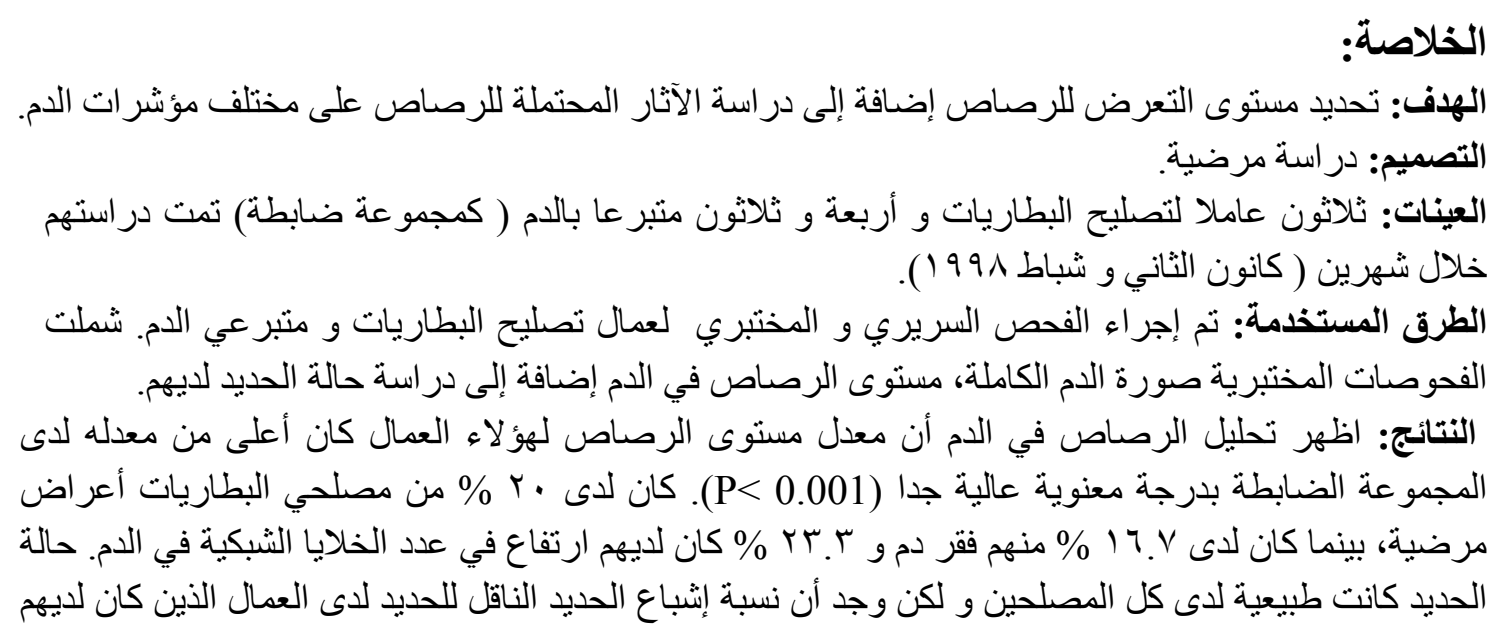




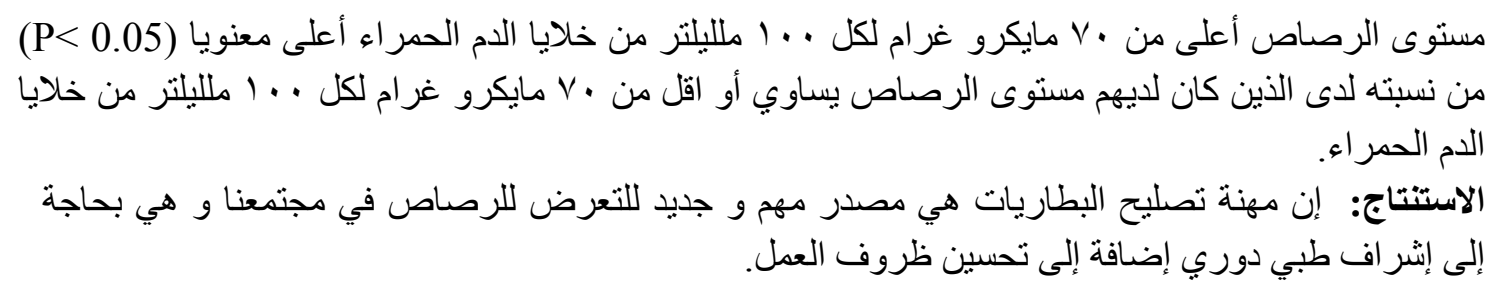

$\mathbf{L}$ ead, the most ubiquitous toxic metal, is detectable in practically all phases of the inner environment and in all biologic systems. There are many sources for lead exposure $^{(1)}$. They include environmental, household and occupational sources ${ }^{(1-4)}$. When a person is exposed to lead, absorption of lead may be via gastrointestinal tract after ingestion or via alveoli of the lung after inhalation. Absorption through the skin is negligible except in cases of organic lead compounds where absorption of lead may be significant $^{(2-5)}$.

The haematological effects of lead intoxication are confined to the red cells and include (1) suppression of haemoglobin synthesis $^{(6-7)}$ (2) Shortening of red cell life $\operatorname{span}^{(8)}$, and (3) direct effect on erythropoiesis $^{(9)}$.

Apart from history and physical examination, laboratory tests used in the diagnosis of lead poisoning can be grouped into $^{(5-12)}$.

Group I: tests that detect the lead body's burden as blood lead level (BLL).

Group II: tests that detect the biologic effects of absorbed lead such as plasma and urinary aminolevulinic acid concentration, erythrocyte aminolevulinic acid dehydratase activity, and erythrocyte protoporphyrin concentration.

The primary therapy for established lead poisoning is cessation of exposure, in addition to symptomatic treatment and chelation therapy. The first and foremost preventive measure is the control of industrial exposure.

\section{Subjects and Methods:}

During a period of 2 months (Jan. - Feb. 1998), 30 males working as battery repairers in Mosul and 34 healthy male blood donors with comparable age as controls were included in this study. Clinical data including age, duration and nature of work, and sign or symptoms were included.

Haematological investigations including complete blood count, Leishmann's stained blood cell morphology, reticulocyte count, and direct Coombs' test were done according to standard methods ${ }^{(13)}$. An atomic absorption spectrophotometric method using a chelation-extraction procedure was used for blood lead level determination ${ }^{(14-15)}$.

Iron status was determined using a colorimetric method using a commercial kit of Randox, England. Statistical analysis was performed ${ }^{(16)}$. 


\section{Results:}

The mean age of the workers group was 26.1 years, with a range of $15-49$ years and for the control group was 25.6 years, with a range of $17-45$ years.

The mean duration of work was 27 months, ranging from 1-72 months. Six of the battery repairers $(20 \%)$ complained of non-specific symptoms including anorexia, dyspepsia, recurrent abdominal colic, pallor was noticed in 5 workers (16.7\%), while lead line was seen in 9 of them (30\%).

Anaemia (a haemoglobin value of less than $13.0 \mathrm{~g} / \mathrm{dl}$ ) was seen in 5 repairers (16.7\%), while reticulocytosis was seen in $7(23.3 \%)$. All the repairers had normochromic normocytic red cell morphology while none of them had basophilic stippling. Direct Coombs' test was negative in all.

The results of $B L L$ and iron status are listed in table (1). Comparison of haematological parameters and iron status in battery repairers grouped according to their BLL is listed in table (2). The nature of ventilation of workplaces appeared to affect the BLL table (3). Nine out of 14 workers in poorly ventilated workplaces (64.3\%) had BLL value above the upper acceptable normal value $(49.26 \mu \mathrm{g} / \mathrm{dl}$ $\mathrm{RBC})^{(17)}$ while none of the workers in wellventilated workplaces had such value.

Table (1): Blood lead concentrations and iron status of the controls and battery repairers

\begin{tabular}{|c|c|c|c|c|}
\hline & Control & battery repairers & \multirow{2}{*}{$P$ - value } \\
\hline & & $(n=34)$ & $(n=30)$ & \\
\hline \multirow{2}{*}{$\begin{array}{c}\text { BLL } \\
\mu \mathrm{g} / \mathrm{dl} \text { RBC }\end{array}$} & $X \pm S D$ & $33.57 \pm 5.23$ & $49.14 \pm 16.1$ & \multirow[t]{2}{*}{$<0.001$} \\
\hline & Range & $20-42.8$ & $32.5-83.4$ & \\
\hline \multirow{2}{*}{$\begin{array}{c}\text { Serum Iron } \\
\mu \mathrm{g} / \mathrm{dl}\end{array}$} & $\mathrm{X} \pm \mathrm{SD}$ & $110.8 \pm 27.4$ & $112.9 \pm 26.2$ & \multirow[t]{2}{*}{ N.S. } \\
\hline & Range & 71 - 178 & $53-158$ & \\
\hline \multirow{2}{*}{$\begin{array}{c}\text { Total Iron Binding Capacity } \\
\mu \mathrm{g} / \mathrm{dl}\end{array}$} & $X \pm S D$ & $335.4 \pm 41.4$ & $343 \pm 46.4$ & \multirow[t]{2}{*}{ N.S. } \\
\hline & Range & $245-403$ & $242-406$ & \\
\hline \multirow{2}{*}{ Transferrin Saturation \% } & $X \pm S D$ & $33.7 \pm 9.2$ & $33.5 \pm 8.96$ & \multirow[t]{2}{*}{ N.S. } \\
\hline & Range & $21-54$ & $20-51$ & \\
\hline
\end{tabular}

Table (2): Comparison of haematological parameters and iron status in battery repairers grouped according to their blood lead concentrations.

\begin{tabular}{|c|c|c|c|c|}
\hline Parameter & $\begin{array}{c}\text { Group I }^{1} \\
X \pm \text { SD }\end{array}$ & $\begin{array}{c}\text { Group II } \\
X \pm S D\end{array}$ & $\begin{array}{c}\text { Group III } \\
X \pm \text { SD }\end{array}$ & Signif. $^{2}$ \\
\hline Number (\%) & 12 (40 \%) & $12(40 \%)$ & $6(20 \%)$ & \\
\hline Haemoglobin (g/dl) & $13.76 \pm 1.44$ & $14.05 \pm 1.36$ & $13.5 \pm 0.88$ & N.S. \\
\hline Haematocrit (\%) & $43.75 \pm 4.59$ & $44.25 \pm 4.76$ & $43.33 \pm 3.25$ & N.S. \\
\hline Reticulocytes (\%) & $3.13 \pm 3.73$ & $1.83 \pm 1.05$ & $1.83 \pm 0.69$ & N.S. \\
\hline Total WBC $\left.\left(\times 10^{9}\right) / L\right)$ & $8.04 \pm 2.62$ & $7.15 \pm 1.74$ & $7.55 \pm 1.44$ & N.S. \\
\hline Neutrophils (x10\%/L) & $4.37 \pm 1.72$ & $3.82 \pm 1.13$ & $4.28 \pm 1.27$ & N.S. \\
\hline Lymphocytes (x10 $/ \mathrm{L})$ & $3.11 \pm 0.92$ & $2.91 \pm 0.80$ & $2.70 \pm 0.46$ & N.S. \\
\hline Eosinophils (x 109/L) & $0.38 \pm 0.29$ & $0.28 \pm 0.15$ & $0.41 \pm 0.12$ & N.S. \\
\hline Serum Iron $(\mu \mathrm{g} / \mathrm{dl})$ & $114 \pm 20.8$ & $106 \pm 31$ & $124 \pm 19.5$ & N.S. \\
\hline Total Iron Binding Capacity $(\mu \mathrm{g} / \mathrm{dl})$ & $361 \pm 37.2$ & $342 \pm 50.8$ & $309 \pm 32$ & N.S. \\
\hline Transferrin Saturation (\%) & $32.1 \pm 7.8$ & $31.5 \pm 9.8$ & $40 \pm 5.3$ & $<0.05^{3}$ \\
\hline
\end{tabular}

${ }^{1}$ Group I includes workers with BLL of less than $40 \mu \mathrm{g} / \mathrm{dl}$ RBC. Group II includes workers With BLL between $40-70$ $\mu \mathrm{g} / \mathrm{dl}$ RBC. Group III includes workers with BLL of more than $70 \mu \mathrm{g} / \mathrm{dl}$ RBC. ${ }^{2}$ Signif.: significance. Statistical comparison between the three groups done by ANOVA test. ${ }^{3}$ Least significant difference test showed a significant difference in the transferrin saturation of workers of group III in comparison with that of members of group I and II. No significant difference is found between members of group I and group II. 
Table (3): Blood lead concentration of the workers in poorly and well ventilated workplaces.

\begin{tabular}{|c|c|c|c|c|}
\hline \multicolumn{2}{|c|}{} & $\begin{array}{c}\text { Workers in well ventilated } \\
\text { workplaces } \\
(\mathrm{n}=16)\end{array}$ & $\begin{array}{c}\text { Workers in poorly } \\
\text { ventilated workplaces } \\
(\mathrm{n}=14)\end{array}$ & P - value \\
\hline \multirow{2}{*}{$\begin{array}{c}\mathrm{BLL} \\
\mu \mathrm{g} / \mathrm{dl} \mathrm{RBC}\end{array}$} & $\mathrm{X} \pm \mathrm{SD}$ & $37.77 \pm 2.81$ & $62.15 \pm 15.17$ & $<0.001$ \\
\cline { 2 - 4 } & Range & $32.5-42.8$ & $42.8-83.4$ & \\
\hline
\end{tabular}

\section{Discussion:}

It is well known that battery manufacturing and reclamation are sources of lead exposure to the workers directly involved in these occupations ${ }^{(18,19)}$. The results of this study confirm this fact. Nine workers (30\%) had a BLL above the upper acceptable normal value. However, none of the workers studied had a blood level indicative of lead toxicity (i.e. all the workers had a blood lead level of less than $160 \mu \mathrm{g} / \mathrm{dl}$ RBC). These results agree with other reports ${ }^{(18-19)}$.

The five anaemic repairers had a mean haemoglobin of $11.8 \mathrm{~g} / \mathrm{dl}$ (ranging from $11.5-12.5 \mathrm{~g} / \mathrm{dl})$. Their BLL ranged from 32.5 - $83.4 \mu \mathrm{g} / \mathrm{dl}$ RBC with a mean value of $50.9 \mu \mathrm{g} / \mathrm{dl}$ RBC. None had basophilic stippling or reticulocytosis, their transferrin saturation was normal in all and ranged from $20-46 \%$ and all had negative direct Coombs' test. Thus iron deficiency and autoimmune haemolysis were excluded, but the cause of anaemia in these 5 repairers is still not clear and suppression of bone marrow erythropoiesis would seem the most probable cause, as was reported by others ${ }^{(3-20)}$.

Reticulocytosis was evident in 7 repairers. Their mean reticulocyte count was 5.1\% (ranging from 3-15\%). Their haemoglobin (c) 2008 Mosul College of Medicine values ranged from $13-14.6 \mathrm{~g} / \mathrm{dl}$, while their BLL ranged from 36.6-75.5 $\mu \mathrm{g} / \mathrm{dl}$ RBC with a mean value of $48.9 \mu \mathrm{g} / \mathrm{dl}$ RBC. Neither their histories nor their haematoiogical investigations gave any clue about the cause of their reticulocytosis, and it seems to be the result of the haemolytic effect of lead on red cells (either due to red cell membrane changes, alteration in the intraerythrocytic enzymes activities, or combination of both) making them more vulnerable to early destruction $^{(8,20)}$.

There was no significant statistical difference in the effects of different concentrations of lead on the haematological parameters studied. The only significant difference $(P \quad<0.05)$ noticed is in the transferrin saturation which was higher in workers with BLL of more than $70 \mu \mathrm{g} / \mathrm{dl}$ RBC table (2). This could be explained by the fact that lead blocks the incorporation of iron into protoporphyrin IX by inhibiting the enzyme ferrochelatase with subsequent increase in serum iron concentration ${ }^{(22)}$.

The nature of ventilation of workplaces of the repairers appeared to be one of the important factors that affect the BLL of these workers. The difference between the mean of BLL of workers in poorly 
ventilated workplaces and those working in well ventilated workplaces $(62.15 \mu \mathrm{g} / \mathrm{dl}$ RBC Vs $37.77 \mu \mathrm{g} / \mathrm{dl}$ RBC) was very highly significant $(P<0.001)$ table $(3)$. This result was expected, as the most important route of absorption of lead in such occupation is the inhalation of lead fume or dust ${ }^{(23)}$.

Finally, it should be stated that the imposed blockade on our country - Iraq, at that time, was responsible for the appearance of this occupation. The replacement of old battery by new one became a real financial burden and forced owners of cars for repairing rather than replacing their old batteries.

\section{References}

1. Goyer RA. Toxic effects of metals. In; Klaassen CD, Amdur MO, Doull J. Casarett and Doull's Toxicology: The Basic Science of Poisons, 3rd ed. Macmillan Publishing Company, 1986; 598-605.

2. Gossel TA, Bricker JD. Principle of Clinical Toxicology, Raven Press Book LTD. 1984; 166-170.

3. Cullen MR, Rubin JM, Eskenazi B. Adult inorganic lead intoxication; Presentation of 31 new cases and a review of recent advances in the literatures. Medicine 1983; 62: 221-247.

4. Ramirez-Cervantes B, Embree TW, Hine $\mathrm{CH}$, et al. Health assessment of employees with different body burden of lead. J Occup Med 1978; 20: 610-617.

5. Rempel D. The lead exposed workers. JAMA 1989; 262: 532-534.

6. Albahaw C. Lead and hemopoiesis. Am J Med 1972; 52: 367-378.
7. White JM. Lead and haemoglobin synthesis. Postgrad Med J 1975; 51: 755-756.

8. Berk PD, Tschudy DP, Sheply CA, Waggoner JG, Berlin NI. Haematological and biochemical studies in a case of lead poisoning. Am J Med 1970; 28: 137-144.

9. Leikin S, Eng G. Erythrokinetic studies of the anaemia of lead poisoning. Pediatrics 1963; 31: 996.

10. Hu H. Heavy metal poisoning. In: Fauci AS, Braunwald E, Isselbacher $\mathrm{KJ}$, et al. Harrison's Principle of Internal Medicine, 14th ed. McGraw Hill Book Company, 1998; 2565-2566.

11.Klein M, Kaminsky P, Duc ML, Duc M. Current diagnosis and treatment of lead poisoning. Rev Med Interne 1994; 15:101-109.

12. Chattopadhyay A, Roberts TM, Jervis RE. Scalp hair as a monitor of community exposure to lead. Arch Environ Health 1977; 32: 226-235.

13.Dacie JV, Lewis SM. Practical Haematology, 8th ed. Churchill Livingstone, 1995; 49-130,457-460.

14. Farrelly RO, Pybus J. Measurement of lead in the blood and urine by atomic absorption spectrophotometry. Clin Chem 1969; 15: 566574.

15. Zinterhofer LJM, Jatlow PI, Fappiano A. Atomic absorption determination of lead in blood and urine in the presence of EDTA, J Lab Clin Med 1971; 78; 664-674.

16. Armitage P, Berry G. Statistical Methods in Medical Research. 2nd ed. Blackwell Scientific Publication, 1987. 
17. Waldron HA. The blood lead threshold. Arch Environ Health 1974; 29: 271-273.

18.A1-Timimi DJ. The adverse health effects of direct and indirect exposure to lead among battery factory workers. J Comm Med Iraq 1990; 3:103-110.

19. Lee BK. Occupational lead exposure of storage battery workers in Korea. $\mathrm{Br} \mathrm{J}$ Ind Med 1982; 39: 283-289.

20.Paglia DE, Valentine WN, Dohlgren JG. Effects of low level lead exposure on pyrimidine $5^{\prime}$ nucleotidase aid other erythrocyte enzymes. J Clin Invest 1975; 56:1164-1169.
21.Selhi HS, White JM. The effects of lead on the red cell membrane, postgrad Med J 1975; 51: 765-769.

22.DeBruin A. certain biologic effects of lead upon the animal organism. Arch Environ Health 1971; 23: 249-264.

23. William MK, King E, Walford J. An investigation of lead absorption in an electric accumulator factory with use of personal samplers. $\mathrm{Br} \mathrm{J}$ Ind Med 1969; 26:202-216. 